\title{
The Integration of the Financial Services Industry: Where are the Efficiencies?
}

\author{
Allen N. Berger \\ Board of Governors of the Federal Reserve System \\ Washington, DC 20551 U.S.A. \\ and \\ Wharton Financial Institutions Center \\ Philadelphia, PA 19104 U.S.A.
}

\begin{abstract}
We examine the efficiency effects of the integration of the financial services industry and suggest directions for future research. We also propose a relatively broad working definition of integration and employ U.S. and European data on financial service industry M\&As to illustrate several types of integration. The analysis suggests that there is a large potential for efficiency gains from integration, but only a relatively small part of this potential may be realized. Integration appears to bring about larger revenue efficiency gains than cost efficiency gains, and most of the gains appear to be linked to benefits from risk diversification.
\end{abstract}

Forthcoming, North American Actuarial Journal 4 (2000)

JEL classification codes: G21, G22, G24, G28, G34, F23, F36

Key words: Banks, Insurance, Securities Firms, Mergers, Efficiency, International Finance.

The opinions expressed do not necessarily reflect those of the Federal Reserve Board or its staff. The author thanks Harold Skipper (the Bowles chairholder) for suggesting the topic of this paper and organizing the symposium; Dave Cummins and Marty Grace for giving excellent discussant comments; Bob Avery, Bob DeYoung, Hesna Genay, Mary Weiss, Greg Udell, and the anonymous referees for very valuable suggestions; and Kelly Bryant and Linda Pitts for outstanding research assistance.

Please address correspondence to Allen N. Berger, Mail Stop 153, Federal Reserve Board, 20th and C Sts. NW, Washington, DC 20551, call 202-452-2903, fax 202-452-5295, or email aberger@ frb.gov. 


\section{Introduction}

The financial services industry is becoming more integrated in a number of ways. In nations around the world, mergers and acquisitions (M\&As) are occurring among some of the largest financial service providers. In Japan, the Fuji Bank-Dai-Ichi Kangyo Bank-Industrial Bank of Japan M\&A and the Sanwa Bank-Tokai BankAsahi Bank M\&As are expected to create the world's largest two banks, respectively, with about \$1.4 trillion and $\$ 1.0$ trillion in assets. In Europe, the UBS-Swiss Bank Corp. M\&A and other consolidation activities also created a number of very large institutions. In the U.S., the recent BankAmerica-NationsBank M\&A created the largest domestic deposit base in the nation.

There is also considerable integration creating universal-type institutions that provide many categories of financial services. For example, the Citicorp-Travelers M\&A created a financial institution that provides commercial banking, securities underwriting, insurance services. Moreover, considerable cross-border integration is taking place in which financial institutions are establishing physical presences in other nations. In Europe, cross-border M\&A activity exceeds domestic M\&As for both the securities and insurance sectors. Recent policy changes around the world -- particularly legislation allowing interstate banking and universal banking in the U.S. and changes that allow easier cross-border entry and common currency in the European Union (EU) -- make it likely that these waves of integration will continue.

The main purposes of this paper are to examine the efficiency effects of the integration of the financial services industry and to suggest directions for future research. In addition, we propose a relatively broad working definition of financial services industry integration, since there is no unanimously accepted definition. We also break down integration into simple and complex types, provide examples of each type, and discuss the different ways that integration may take place. Additionally, we use some U.S. and European data on financial service industry M\&As to illustrate the importance of several types of integration.

Our review of the research on the efficiency effects of integration covers three complex types of financial integration. These are 1) the national consolidation of financial institutions within a single product category, such as commercial banking, securities, or insurance; 2) the integration of multiple categories of financial services into universal-type organizations, such as combining commercial banks with insurance companies; and 3) the consolidation of the financial services industry across international borders. 
We include as the potential efficiency effects of integration any consequences that may affect shareholder value other than changes in market power. This broad treatment covers the scale efficiency, scope efficiency, and X-efficiency consequences of integration, and includes both cost and revenue effects. An important caveat to our analysis is that the availability of relevant research on the efficiency of the financial services industry is uneven, requiring a considerable amount of extrapolation to draw meaningful conclusions. Most of the research is on U.S. commercial banks, with some findings for the insurance industry, and very little for the securities industry. Fortunately, the available research generally supports the notion that the efficiency consequences of integration are similar across financial industries and across nations. There is also little direct evidence on the efficiency effects of the integration of the providers of different categories of financial services into universal-type organizations. We must largely extrapolate from scope efficiency studies within one category of financial services and from simulation studies of risk diversification benefits. Similarly, there is relatively little research on the efficiency effects of the cross-border integration of financial institutions, a topic which grows in importance as financial markets become more globalized.

Section 2 provides background material on financial services industry integration, including our proposed working definition, the breakdown of types of integration, the ways that integration may take place, and some international data on integration. Section 3 briefly reviews the economic efficiency concepts employed in the analysis. The next sections review the research on the efficiency effects of the national integration of institutions within a single product category (Section 4); the integration of financial service providers into universal-type organizations (Section 5); and the international integration of financial institutions (Section 6). Section 7 assesses the findings and suggests directions for future research.

By way of preview, our analysis suggests that there is a large potential for efficiency improvements from integration, but that only a small part of this potential appears to be realized. Perhaps surprisingly, our findings suggest that integration appears to bring about larger revenue efficiency gains than cost efficiency gains, and that most of these gains appear to be from the benefits of risk diversification. Our analysis also suggests that much research remains undone and suggests ways to address the unanswered questions.

\section{Background material on financial services industry integration}

We begin our background material with a proposed working definition of financial services industry 
integration as inclusive of any event that joins two or more financial service organizations or combines two or more dimensions of the production or distribution of financial services. By production of financial services, we mean underwriting of financial contracts, intermediation, risk management, payments processing, and other backoffice operations. By distribution, we mean the direct contact with customers, including sales, marketing, provision of services, and other front-office operations.

Several simple types of integration are illustrated in Table 1, along with an example of each. Scale integration occurs when the production or distribution of financial services is consolidated into fewer, larger organizations, such as occurs when there is an M\&A of similar financial institutions. Scope integration occurs when the range of services produced or distributed by financial institutions is expanded. This may take place when institutions move from offering a single category of financial services to become universal-type organizations that provide commercial banking, investment banking, insurance, etc. in a single organization through M\&As or other types of expansion. Geographic integration occurs when financial institutions expand to produce or distribute financial services in an expanded set of locations, such as takes place in cross-regional M\&As or when institutions set up subsidiaries or offices in other locations. International integration occurs when institutions expand across borders through M\&As, establishment of new subsidiaries or offices, or other means. International integration often requires organizations to adapt to differences in language, culture, currency, regulatory/supervisory structures, etc., as well as geographic distance. Financial service providers may also horizontally integrate their production or distribution systems or vertically integrate by combining production with distribution in the same organization (examples given in Table 1). This list of simple types of integration is obviously not complete and there is unavoidable overlap among even these simple types.

As illustrated in these examples, integration can take place in a number of ways, including through M\&As among organizations, or through individual organizations expanding on their own or integrating their own production or distribution systems. Integration may alternatively be accomplished with the same industry structure through the formation of correspondent networks, syndicates, shared-access networks, or alliances in which the production or distribution of services is collectively shared or parceled out.

Importantly, any one integration event is usually complex, involving several of the simple types of integration simultaneously. Consider, for example, an M\&A between two organizations that each previously 
operated in different nations and provided a different set of financial services. Such an M\&A will result in scale integration by creating a larger total organization, scope integration by providing a broader array of services, geographic integration by creating a more geographically dispersed organization, and international integration by creating a multinational organization. Such an M\&A may also involve the different types of simple horizontal and vertical integration of production and distribution systems.

It is not possible to cover thoroughly the efficiency effects of all types of financial integration in one paper of manageable size. Instead, we review what is known and unknown and suggest directions for future research on the efficiency effects of three complex types of financial integration. Each of the three types chosen has significant current and likely future integration activity, a high degree of policy significance, and a reasonable body of extant efficiency research available to be reviewed. The three complex types of integration chosen, their correspondence to the simple types, and the research subjects reviewed are summarized in Table 2.

The first complex type of integration covered is the national integration of financial institutions within a single product category. This always involves scale integration and may also involve scope and geographic integration as well. The most substantial within-nation integration usually takes place through M\&A activity.

The second complex type of integration covered is the integration of the providers of different categories of financial services into universal-type organizations. This typically involves scale and scope integration and may also involve geographic and international integration as well. Universal-type integration often takes place through M\&As among commercial banks, securities firms, and/or insurance companies.

The third complex type of integration considered here is the international consolidation of financial institutions. This typically involves scale, geographic, and international integration, and may also involve scope integration as well. This type of integration often takes place through M\&As among financial service organizations in different nations.

Table 3 summarizes data on M\&A activity that represent these three types of complex integration. The data reported are for M\&As of large, publicly traded corporations, and so exclude M\&As of small targets and other types of integration activity. Panel A reports the flow of domestic M\&A activity within the U.S. (columns 1-3) and within individual European nations (columns 4-6). Panel B reports the corresponding information for cross-border or international M\&As. The values shown are the sums of the market values of all target institutions 
over 1985-1997, and the percentages of the U.S. or European activity these represent.

In both the U.S. and Europe, most of the domestic M\&A activity is national integration of financial institutions within a single product category, represented by the diagonal elements of the two $3 \times 3$ matrices in Panel A. In both the U.S. and Europe, banks-consolidating-with-other-banks was the most voluminous form of domestic M\&A in terms of market values. Not surprisingly, the domestic M\&A activity within category is much greater in the U.S., particularly in the banking sector. In part, this reflects the gradual deregulation over time of interstate banking restrictions, culminating in the Riegle-Neal Act that removed most of the remaining interstate barriers as of June 1, 1997. The European nations generally allowed nationwide banking prior to the start of the sample period in 1985 .

The off-diagonal elements of the $3 \times 3$ matrices in both Panels A and $\mathrm{B}$ of Table 3 correspond to consolidation of the providers of different categories of financial services into universal-type organizations. The off-diagonal elements in Panel A give the domestic consolidation of different categories of financial institution. Not surprisingly, a higher proportion of domestic European M\&A activity is of the universal type, given the fewer regulatory restrictions in Europe. Consolidation across sectors comprised 37.5\% of domestic M\&A activity in Europe versus only $13.4 \%$ of domestic activity in the U.S. The off-diagonal elements in Panel B indicate the international consolidation of different financial institutions across categories. Again, the consolidation into universal-type organizations shown in the off-diagonal elements of the matrix are smaller than the on-diagonal integration within a single product category. Again, more of the European activity is of the universal type than in the U.S.

The international M\&As shown in Panel B of Table 3 correspond to the third type of complex integration we cover in our review. As already noted, for both the U.S. and Europe, most of the international M\&A activity is within a single product category. However, a difference from the domestic data is that insurers-consolidatingwith-other-insurers is the largest single category of cross-border M\&As, rather than banks-consolidating-withother-banks as in the domestic M\&As. In the U.S., the domestic within-sector M\&As dominate the cross-border M\&As for banks, securities firms, and insurers, but in Europe, the cross-border within-sector M\&As dominate the domestic M\&As for both the securities and insurance sectors. This relatively greater emphasis on international M\&As in Europe is not surprising, given that the individual nations are much smaller, and a 
sequence of legal changes in the European Union over the past two decades, known as the Single Market Programme, have made it easier for financial institutions to operate across borders within the participating European nations.

Looking ahead, we can expect more of all of our three types of complex integration activity. There is likely to be more domestic consolidation within the commercial banking sector in the U.S. (first type) and more international consolidation of all types in Europe (second and third types) as the adjustments to the Riegle-Neal Act and the Single Market Programme continue. Additional integration is likely to be forthcoming as a result of more recent policy changes. In the U.S., more domestic integration of the providers of different categories of financial services into universal-type organizations (second type) is likely to be precipitated by the recent passage of the Gramm-Leach-Bliley Act that greatly expands banking powers. In Europe, international consolidation of all types (second and third types of integration) are likely to be spurred by the recent adoption of monetary union, which may lower the costs or raise the revenues from cross-border operations in other participating nations.

\section{Brief review of efficiency concepts}

Our broad treatment of the potential efficiency effects of integration includes any consequences that affect shareholder value other than pure changes in the exercise of market power in setting prices. Here we briefly review some of the efficiency concepts involved, but we refer the reader interested in additional details to more comprehensive sources for information on these concepts as applied to banking (e.g., Berger and Mester 1997) or insurance (e.g., Cummins and Weiss 2000a), or for information on measurement methods and efficiency findings (Berger and Humphrey 1997).

Cost efficiency refers to how close an institution's costs are to those of a best-practice institution. Efficiency is measured relative to the best practice within the available data set, since engineering information on the technology of financial institutions is not available. Cost efficiency is measured using a standard cost function in which variable costs depend on the quantities of outputs, the prices of variable inputs, any fixed inputs or outputs, and other environmental conditions. The main types of cost efficiency are scale efficiency, scope efficiency, and X-efficiency.

Cost scale efficiency refers to how close average costs are for a best-practice firm at a given scale and 
mix of output to the average costs of a best-practice firm at the minimum-average-cost point for that product mix. The integration of financial service providers into larger institutions can create cost scale efficiency gains through spreading fixed costs over more units of output, taking better advantage of technology, issuing securities in larger sizes, and many other ways. Integration may alternatively result in cost scale efficiency losses by creating organizational diseconomies in managing the larger organization.

Cost scope efficiency refers to how close the sum of costs for two best-practice firms that each specialize in some of the outputs are to the costs of a single best-practice firm that produces all of the outputs. Cost scope efficiency gains from integration may occur through sharing physical inputs, information systems, databases, or other means. Cost scope efficiency losses from integration may occur because of organizational diseconomies from producing or distributing more products, particularly if the senior management strays far from its area of core competency.

Cost X-efficiency refers to how close a firm's actual costs are to the costs of a best-practice firm producing the same outputs. Cost X-inefficiency may arise because managers use more inputs than would a bestpractice firm (technical inefficiency) or because they employ an input mix that does not minimize costs for a given input price vector (allocative inefficiency). Financial integration may increase cost X-efficiency, for example, if the acquiring institution is more efficient than the target, and the acquirer spreads superior managerial expertise over more resources. Integration may alternatively reduce X-efficiency in some circumstances, such as if the target is in another region or nation, making it difficult to overcome barriers of distance, differences in language, etc., and operate efficiently.

Revenue efficiency is analogous to cost efficiency and refers to how close an institution's revenues are to best-practice revenues under the same environmental conditions. Revenue efficiency is usually measured using the alternative revenue function in which output prices are free to vary and reflect customer preferences and willingness to pay for the scale, scope, or quality of the institution's outputs.

Profit efficiency is the most comprehensive efficiency concept that embodies both cost and revenue efficiency. Profit efficiency most closely corresponds to the goal of value maximization and accounts for errors on the output side as well as those on the input side. Profit efficiency appropriately requires that the same amount of managerial attention be paid to raising a marginal dollar of revenue as to reducing a marginal dollar of costs 
and avoids misleading impressions that may occur by focusing on only costs or revenues.

Cost, revenue, and profit efficiency are generally accepted concepts and do not need to be justified. However, one source of these efficiencies that is not always accepted is risk diversification. Given that risk diversification plays an important role in our analysis below, we justify here our use of risk diversification as a potential source of efficiency gains from integration.

Under an assumption of perfect capital markets, risk considerations would not affect shareholder value and therefore would not affect efficiency. Investors would diversify their own risks, perhaps by owning claims on institutions in different regions or nations. However, there are at least five types of market imperfections that encourage efficient institutions to diversify risks.

The first is informational opacity. Under the modern theory of financial intermediation, financial institutions are delegated monitors who produce information about informationally opaque assets, and diversification of large pools of these assets is part of the solution to the information problems. That is, institutions diversify to improve their credibility as delegated monitors of financial assets. Institutions that are better diversified may have lower costs of capital -- lower interest rates paid on their debt and other contingent claims, lower required returns on equity -- because of improved credibility and reduced risks faced by investors.

Second, even without information problems, risk diversification by financial institutions may improve revenue efficiency by allowing them to better provide the outputs of risk-pooling and risk-bearing. All financial institutions provide financial guarantees, such as loan commitments by commercial banks, commitments to underwrite or provide secondary markets for securities by investment banks, or pay off policyholders in the event of property damage, liability, medical costs, or death by insurance companies. The value of these guarantees and the capacity to provide them depends on keeping risks under control and assuring the customer that the guarantees will be honored and the promised future payments will be made (e.g., Borch 1962, Cummins, Doherty, and Lo 1999).

The third market imperfection is the costs associated with financial distress, bankruptcy, or loss of franchise value in the event of financial institution failure or closure. Reduction of risk through geographic, product line, or international diversification or other means may reduce the impact on shareholder wealth of the expected costs of these problems. 
The fourth market imperfection is government regulation and supervision. Prudential regulation and supervision — such as risk-based capital requirements, prompt corrective action rules, threats of formal actions or closure - impose costs on risk-taking and giving incentives for value maximizing institutions to reduce risk to avoid government penalties.

A final market imperfection is illiquidity. The shareholders of a small financial institution may not be able to easily diversify their own risks because their institution's shares are not publicly held or are very thinly traded. Such shareholders (who are also often managers of the institution) may prefer that the institution be managed in a risk-averse fashion.

Risk diversification achieved through financial integration may be manifested in lower costs because of reduced risk premiums on debt and other contingent claims or lower costs of compliance with prudential regulation/supervision. Diversification may also result in higher revenues because of the enhanced value of financial guarantees or greater capacity to issue them by safe financial institutions. Higher average revenues may also result if the institutions use some of the gains from diversification to make higher risk-higher expected return investments because of reduced market and regulatory/supervisory pressure. Thus, improvements in risk diversification may be associated with improved cost efficiency and revenue efficiency.

\section{The efficiency effects of national integration of institutions within a single product category}

As noted above, national integration of institutions producing or distributing within the same product category typically involves scale and geographic integration, and usually takes place through M\&As. Our research subjects covered here are the scale efficiency of financial institutions, including both cost and revenue effects (subsections 4.1 and 4.2, respectively), the X-efficiency effects of geographic integration, including the effects on the risk-expected return tradeoff, the cost and profit X-efficiency of cross-regional activity (subsection 4.3), and the effects of M\&As on cost and profit X-efficiency (subsection 4.4). That is, we assess the efficiency implications of this complex type of integration by assessing the efficiency effects of the increase in scale, the increase in geographic spread, and the M\&A process itself.

Importantly, although we review these efficiency topics in the context of assessing the effects of national integration of single-product-category institutions, the research results are assumed to apply to our other two complex types of integration (universal-type, international) to the extent that these types of integration also 
increase scale, geographic spread, or occur through M\&As.

\subsection{Cost scale efficiency effects of integration}

The integration of financial service providers into larger institutions can create cost scale efficiency gains due to conventional scale economies, such as spreading fixed costs over more units of output; taking advantage of technologies that require large scale to achieve minimum average cost; issuing securities in larger sizes to reduce the impact of fixed issue costs; reusing managerial expertise, information or physical inputs; or economies of scale in marketing/brand name recognition. There may also be cost scale economies more particular to financial institutions, such as economies of scale in monitoring the risks of counterparties; economizing on transactions costs in dealing with larger accounts or securities; or access to complex financial instruments and risk management models. To the extent that larger portfolios result in improved risk diversification, there may also be cost scale economies from reduced cost of capital.

Integration may alternatively result in cost scale efficiency losses from organizational diseconomies to operating a large organization. It may be difficult to monitor the behavior of lower-level decision makers like loan officers or securities or insurance underwriters, who are further away from senior management on the organizational chart. There may also be organizational diseconomies from providing the larger set of products typically associated with large financial institutions. For example, it may be costly to provide relationship-based services to retail household and small business customers along with the capital market services typically provided to the large wholesale customers by large financial institutions.

Most of the research on commercial bank cost scale efficiency found that the average cost curve had a relatively flat U-shape with medium-sized banks being slightly more cost scale efficient than either large or small banks. Average costs were usually found to be minimized somewhere in the wide range between about $\$ 100$ million and \$10 billion in assets (e.g., Berger, Hanweck, and Humphrey 1987, Hunter, Timme, and Yang 1990, Noulas, Ray, and Miller 1990). Similar U-shaped average cost curves or conflicting cost scale results were found for securities firms (Goldberg, Hanweck, Keenan, and Young 1991) and insurance companies (e.g., Yuengert 1993, Gardner and Grace 1993, Cummins and Zi 1998).

It is sometimes argued that scale efficiency gains from integration will be most prevalent when the combining institutions in the same local markets. This may allow for horizontal integration of distribution or 
production systems through closing and combining retail branch offices or back-office operations. However, studies of the scale efficiency effects of bank M\&As with substantial local market overlap and research on branch office scale efficiency suggest little or no gain from this source (e.g., Berger and Humphrey 1992, Akhavein, Berger, and Humphrey 1997, Berger, Leusner, and Mingo 1997).

The findings reviewed thus far generally suggest no cost scale efficiency gains from integration, except for very small institutions. However, most of this research used data on financial institutions from the 1980s, and it is possible that recent technological progress may have increased scale economies in producing financial services. The tools of financial engineering, such as derivative contracts, off-balance-sheet guarantees, and risk management may be more efficiently exploited by large institutions. Some new delivery methods for customer services, such as Internet banking, phone centers, and ATMs, may also exhibit greater economies of scale than traditional branching networks (Radecki, Wenninger, and Orlow 1997). As well, advances in payments technology may have created scale economies in back-office operations and network economies that may be more easily exploited by large or networked institutions (e.g., Bauer and Hancock 1993, Bauer and Ferrier 1996, Hancock, Humphrey, and Wilcox 1999). Consistent with these arguments, some recent research on bank cost scale efficiency using data from the 1990s suggests that there may be substantial cost scale economies even at larger bank sizes, possibly due in part to technological progress (Berger and Mester 1997). Similarly, a recent study using data mostly from the 1990s found that the largest insurers had the highest cost and revenue efficiency (Cummins 2000). An important caveat is that technologies embodying scale economies may currently or in the future be accessed at low cost by small institutions through franchising, outsourcing, or shared access to networks.

\subsection{Revenue scale efficiency effects of integration}

The increase in scale associated with integration may create revenue scale economies because some customers may need or prefer the services of larger institutions. For example, some retail customers may prefer the convenience of access to larger networks of offices, ATMs, or other facilities. As well, large wholesale customers may need loan facilities, debt or equity issues, or group insurance policies in quantities that cannot be handled by small institutions. To the extent that larger portfolios result in improved risk diversification, there may also be revenue scale economies from the enhanced value and capacity to issue financial guarantees and the 
opportunity provided by market participants and regulators/supervisors to make higher risk-higher expected return investments.

Some small retail customers may prefer the more personalized or relationship-based services associated with small financial institutions, creating revenue scale diseconomies. It is possible that the most efficient market structure would include both large and small institutions to serve different customer niches.

Measured revenue scale efficiency effects of integration may also reflect any cost scale efficiency gains or losses that are manifested in the form of changes in financial service quality that are difficult to measure. For example, if a larger scale reduces costs and firms choose to spend part of those savings on improving service quality, this may be measured as an increase in revenue efficiency as customers pay a higher price for the increase in quality.

A few studies have examined the effects of financial institution scale on revenue efficiency or profit efficiency (which incorporates both cost and revenue efficiency). The results are ambiguous. There is some evidence of mild revenue scale economies (Berger, Humphrey, and Pulley 1996), but profit efficiency is sometimes measured as being highest for large institutions (Berger, Hancock, and Humphrey 1993, Berger, Cummins, Weiss, and Zi 2000, Cummins and Weiss 2000b), highest for small institutions (Berger and Mester 1997), or about equal for large and small institutions (Clark and Siems 1997).

\subsection{X-efficiency effects of increased geographic integration}

National integration of institutions within a product category (as well as our other two complex types of financial integration) often involves geographic integration, as institutions expand into new local markets. We consider here two types of evidence that may reflect the X-efficiency effects of geographic integration, 1) evidence on improvements in the institutions' risk diversification, and 2) evidence on the cost and profit X-efficiency of cross-regional banking.

\subsubsection{Improvements in risk diversification}

Geographic integration may improve efficiency by diversifying risks because the returns on loans, securities, and insurance policies, and other financial instruments issued in different locations may have relatively low or negative correlations. As noted above, improved diversification may increase both cost efficiency (reduced risk premiums on debt/contingent claims, lower regulation/supervision costs) and revenue efficiency (enhanced 
value/capacity for financial guarantees, increased opportunity to make high risk-high expected return investments). One study examined the correlations among bank earnings in eight regions of the U.S. and found that many region pairs had fairly low correlations, particularly when the regions were noncontiguous (Berger and DeYoung 2000).

The available empirical evidence research suggests that geographic integration has helped diversify risks. The literature on commercial banks in the U.S. generally found that larger, more geographically integrated institutions tend to have better risk-expected return tradeoffs (e.g., McAllister and McManus 1993, Hughes, Lang, Mester, and Moon 1996, 1999, Demsetz and Strahan 1997, Hughes and Mester 1998). There is also some evidence that reductions in risk are associated with higher bank profits, due primarily to lower rates paid on uninsured purchased funds, at least during some time periods (Berger 1995). Similarly, international integration has been found to improve the risk-expected return tradeoff and profit efficiency in the reinsurance industry (e.g., Cummins and Weiss 2000b).

\subsubsection{The cost and profit $X$-efficiency of cross-regional activity}

There may be efficiency difficulties with geographic integration in part because of organizational diseconomies to operating or monitoring an institution from a distance. Operating problems could include turf battles between staff in different locations or high costs and turnover in getting upper level managers to move to other locations. Monitoring problems may make it difficult to evaluate the behavior and effort of managers in a distant market or make it difficult to determine how well they are performing relative to other institutions in that market. Organizational diseconomies may also make it difficult to establish and maintain some retail deposit, mutual fund, and insurance policy relationships with households or lending, investment, and group insurance relationships with small and mid-sized enterprises, because such accounts may require local information and a local focus. Some customers may also simply prefer to frequent locally-based financial service organizations. These difficulties may be manifested in higher costs of providing the same financial services or lower revenues from problems in providing the same perceived or actual quality and variety of services as local institutions.

It is also possible that some efficiently managed institutions are able to overcome these cross-regional disadvantages and operate more efficiently than locally-based domestic institutions in other regions. These organizations may have high efficiency in regions distant from their headquarters by spreading their superior 
managerial skills or best-practice policies and procedures over more resources or by taking advantage of the geographic diversification of risks. These benefits of better management and risk diversification may be manifested as improvements in either cost or revenue efficiency or both.

The X-efficiency effects associated with geographic integration are the net effects of these advantages for efficient organizations, the organizational diseconomies to operating or monitoring from a distance, and any other factors associated with operating in many locations. One study evaluated the cost and profit X-efficiency effects of cross-regional banking in the U.S. and found that on net, the efficiency advantages and disadvantages of geographic expansion approximately cancel each other out (Berger and DeYoung 2000). For the most part, institutions headquartered outside a U.S. region had nearly the same measured cost and profit X-efficiency on average as institutions headquartered inside the same region. However, there was also some important heterogeneity in the results. The data suggested that it may be very inefficient to operate small banks from great distances (more than one region away), but large banks may be efficiently managed from such distances. In addition, the efficiency advantages in managing institutions from great distances is primarily manifested in higher revenues, rather than lower costs, consistent with the possibility that the main gains may accrue from the benefits of risk diversification.

\subsection{Dynamic cost and profit X-efficiency effects of M\&As}

There are also likely to be dynamic efficiency effects if the integration takes place through M\&As. M\&As are dynamic events that often involve changes in organizational focus or managerial behavior that change the X-efficiency of the organizations - moving them toward or away from the optimal point on the best-practice efficient frontier. X-efficiency may be improved, for example, if the acquiring institution is more efficient ex ante and brings the efficiency of the target up to its own level by spreading its superior managerial expertise or policies and procedures over more resources. The M\&A event itself may also improve X-efficiency by awakening management to the need for improvement or by being used as an excuse to implement substantial unpleasant restructuring. Alternatively, X-efficiency may worsen because of the costs of consummating the M\&A (legal expenses, consultant fees, severance pay, etc.) or disruptions from downsizing, meshing of corporate cultures, or turf battles. X-efficiency may also decline because of organizational diseconomies to operating or monitoring an institution that is more complex in dimensions other than just the scale and geographic spread discussed above. 
The extant research suggests that there is substantial potential for both cost and profit X-efficiency improvement from integration. Average cost X-efficiency of about $80 \%$ and average profit X-efficiency of about $50 \%$ are typical findings (Berger and Humphrey 1997). These findings suggest that on the order of about $20 \%$ of financial institution costs and on the order of $50 \%$ of potential profits were lost due to X-inefficiency. Simulation evidence also suggests that large X-efficiency gains are possible if the best-practice acquirers reform the practices of inefficient targets (Shaffer 1993).

The research also suggests that many institutions engage in M\&As for the purpose of improving Xefficiency. Many studies have found that acquiring institutions are more efficient ex ante than targets in the banking, insurance, and credit union industries (e.g., Berger and Humphrey 1992, Cummins, Tennyson, and Weiss 1999, Fried, Lovell and Yaisawarng 1999). It has also been found that acquiring banks bid more for targets when the M\&A would lead to significant diversification gains, consistent with a motive to improve the risk-expected return tradeoff and increase revenue and profit X-efficiency (Benston, Hunter and Wall 1995).

A number of studies measured the change in cost X-efficiency after M\&As. Studies of U.S. banks generally showed very little or no cost X-efficiency improvement on average from the M\&As of the 1980s, on the order of $5 \%$ of costs or less (e.g., Berger and Humphrey 1992, DeYoung 1997, Peristiani 1997). Studies of U.S. banks and other types of financial institutions using 1990s data are mixed, but sometimes showed more cost efficiency gains (Berger 1998, Rhoades 1998, Cummins, Tennyson, and Weiss 1999, Fried, Lovell, and Yaisawarng 1999). Studies of M\&As of credit institutions in Europe found that some groups of M\&As tended to improve cost efficiency, whereas other types tended to decrease cost efficiency (Vander Vennet 1996). Studies of Italian banks (Resti 1998) and U.K. building societies (Haynes and Thompson 1999) found significant cost efficiency gains following M\&As.

Studies of profit X-efficiency more often found gains from M\&As. Studies of the profit efficiency effects of U.S. bank M\&As from the 1980s and early 1990s found that M\&As improved profit X-efficiency, and that this improvement could be linked to an increased diversification of risks and an improved risk-expected return tradeoff (Akhavein, Berger, and Humphrey 1997, Berger 1998). After consolidation, the institutions tended to shift their asset portfolios from securities to loans, have more assets and loans per dollar of equity, and to raise additional uninsured purchased funds at reduced rates, consistent with a more diversified portfolio that 
allows them to shift into higher risk-higher expected return investments. Other studies using similar measures to profit X-efficiency found consistent results (e.g., Berger and Mester 1999, Cummins, Tennyson, and Weiss 1999, Hughes, Lang, Mester, and Moon 1999).

There are also a number of event studies of the effects of M\&As on stock market values. The change in the total market value of the acquiring plus the target institution (adjusted for changes in overall stock market values) associated with an M\&A announcement embodies the present value of expected future changes in both efficiency and market power. Although these effects cannot be disentangled, the change in market value may be viewed as an understatement of the expected efficiency improvement, since it is unlikely that M\&As would reduce the market power of the participants.

The empirical results are mixed. Some studies of U.S. bank M\&As found increases in the combined value around the times of M\&A announcements (Cornett and Tehranian 1992, Zhang 1995), others found no improvement in combined value (Hannan and Wolken 1989, Houston and Ryngaert 1994, Pilloff 1996), while still others found that the measured effects depended upon the characteristics of the M\&A (e.g., Houston and Ryngaert 1997). A study of domestic and cross-border M\&As involving U.S. banks found more value created by the cross-border M\&As (DeLong 1999). A study of European bank M\&As found positive abnormal combined returns, but these were not statistically significant (van Beek and Rad 1997). Another study of European M\&As found positive combined returns, mostly driven by domestic bank-to-bank deals and diversification of banks into insurance (Cybo-Ottone and Murgia 1998).

\section{The efficiency effects of the integration of providers into universal-type organizations}

The integration of the providers of different categories of financial services into universal-type organizations typically involves scale and scope integration and may also involve geographic and international integration. The research subjects covered here are the cost and revenue scope efficiency effects of universal-type integration (subsections 5.1 and 5.2, respectively). However, as noted above, much of the findings are extrapolated from scope efficiency studies within one category of financial services and from simulations of the risk diversification benefits of universal-type integration.

\subsection{Cost scope efficiency effects of universal-type integration}

The integration of financial service providers into universal-type organizations can create scope 
efficiency gains from sharing physical inputs like offices or computer hardware; employing common information systems, investment departments, account service centers, or other operations; obtaining capital by issuing debt or equity in larger issue sizes; or reusing managerial expertise or information. For example, a consolidated commercial bank and insurer may lower total costs by integrating their distribution systems. They may cross-sell using each other's customer database at a lower cost than building and maintaining two databases. Similarly, integration in the production of financial services may occur because information reusability may reduce costs when a universal bank acting as an underwriter conducts due diligence on a customer with whom it has had a lending or other relationship. For example, it has been found that U.S. banks certify their private information about firms with whom they have had a lending relationship when the Section 20 affiliate of their bank holding company is underwriting these firms' securities (Gande, Puri, Saunders, and Walter 1997).

Financial institutions may also be able to make cost improvements from integrating the production of different categories of financial services through risk diversification, since the returns associated with banking, securities, and insurance generally have relatively low correlations. As discussed, risk diversification may reduce the cost of capital and the costs of complying with prudential regulation/supervision.

Cost scope efficiency losses may also arise from universal-type combinations because of organizational diseconomies from offering a broad range of products. For example, it may be difficult to operate or monitor commercial banking, investment banking, and insurance underwriting operations because senior managers may each have expertise in only one of these fields. That is, it may be more efficient for managers to focus on core businesses and their core competencies, rather than trying to manage or monitor unfamiliar lines of business. Under certain circumstances, the diversification of activities may result in a reduction of the monitoring incentive by the financial institution, which could, in turn, raise risk premiums paid by the institution and increase its costs of compliance with prudential regulation/supervision (Winton 1999).

Cost scope efficiencies are evaluated empirically by comparing the costs of joint production of a given output vector under given environmental conditions against the combined costs of two hypothetical specializing firms that produce the same total output vector under the same conditions. These efficiencies are often difficult to estimate because there may be no specializing firms in the data sample, creating extrapolation problems for evaluating costs of hypothetical specializing firms with zero outputs for some products. As a result, many studies 
use measures that evaluate at points near zero outputs (but within the bounds of the data) or use concepts such as expansion-path subadditivity which combine scale and product mix efficiencies.

The relatively few studies of cost scope efficiencies associated with universal banking in continental Europe are mixed. One study of European universal banking found very small scope economies (Allen and Rai 1996), one study found some limited evidence of scope economies, but no consistent evidence of expansion-path subadditivity (Vander Vennet 1999), and one study found mostly diseconomies of producing loans and investment services within German universal banks (Lang and Welzel 1998). However, these studies of universal banking in banking-oriented financial systems may not be good predictors of universal banking as it evolves in the future in more market-oriented systems.

Some inference about the efficiency effects of universal-type integration may be taken from the research on scope efficiency within a single category of financial institution. Although there are exceptions, the empirical studies usually found very little evidence of substantial cost scope economies or diseconomies within the banking industry, within the securities industry, or within the insurance industry (e.g., Berger, Hanweck, and Humphrey 1987, Goldberg, Hanweck, Keenan, and Young 1991, Noulas, Miller, and Ray 1993, Berger, Cummins, Weiss, and $\mathrm{Zi} 2000)$.

It is not known how well the research on cost scope efficiencies within a category of financial institution represent the efficiencies across institution categories, although we suspect that cost scope efficiency effects would be more favorable within a category of financial services than across categories. It seems likely that physical inputs, information systems, investments, account service, managerial expertise or information to be shared would be more similar within an institution category and therefore more likely to generate cost scope efficiency gains. It also seems likely that the organizational diseconomies of operating or monitoring less similar services in universal-type organizations are likely to be worse than those in operating or monitoring more similar services within a single category of financial services. Overall, this research suggests very little, if any, cost scope efficiency gains from universal-type financial integration.

\subsection{Revenue scope efficiency effects of universal-type integration}

Financial institutions may be able to make revenue efficiency gains by integrating distribution systems and cross-selling different categories of financial services. These economies may occur because of consumption 
complementarities arising from reductions in consumer search and transactions costs. For example, some customers may be willing to pay more for the convenience of one-stop shopping for their commercial banking and insurance needs. Similarly, a corporate customer may prefer to reveal its private information to a single consolidated entity that provides its commercial and investment banking needs. Revenue efficiency gains can also arise from sharing the reputation that is associated with a brand name that customers recognize and prefer. These reputation economies might arise, for instance, if a universal bank levers off its reputation built in commercial banking when forging a stronger reputation in investment banking, or vice versa (Rajan 1996). ${ }^{1}$ Financial institutions may also be able to diversify risks by combining different categories of financial services, raising revenues because of the enhanced values and capabilities of issuing financial guarantees and improved opportunities to make high risk-high expected return investments.

The integration of different categories of financial institutions may alternatively create revenue scope efficiency losses. This may occur if specialists in different categories of financial services have better knowledge and expertise in their areas of core competence and can better tailor products for individual customers, and thereby charge higher prices than joint producers. Revenue scope diseconomies might also arise to the extent that combining commercial banking and investment banking creates the appearance of conflicts of interest. The market may underprice securities underwritten by a universal bank for its existing loan customers because of concerns that the proceeds from the issue will be used to enhance the value of distressed loans extended to that customer by the bank. As a result, commercial loan customers may prefer not to use their own universal bank's underwriting services, although some evidence suggests that universal banks have been able to successfully address this problem (e.g., Puri 1996, Gande, Puri, Saunders, and Walter 1997, Kroszner and Rajan 1997).

Finally, integration may create revenue scope efficiency losses if it worsens the risk-expected return tradeoff and lowers expected revenues. For example, an institution may be more likely to fail or have higher bankruptcy costs in the event of failure if it is combined with another category of financial institution with a low expected return and a high variance of returns that are highly correlated with the returns of the first institution.

\footnotetext{
${ }^{1}$ For example, some recent evidence suggests that the Solomon Smith Barney unit of Citigroup has been successful in selling securities services to the corporate loan customers of the commercial bank unit Citibank, although the "financial supermarkets" of the 1970s and 1980s (e.g., Sears Roebuck, American Express) were often not successful (Smith and Gasparino 2000).
} 
The integration of different categories of financial services may also lower expected revenues if the lack of knowledge and expertise of senior management in categories of financial services outside their core competence results in worse operating performance and poorer risk management, requiring the organization to engage in lower risk-lower expected return activities to keep risks under control.

There is very little research available on the revenue scope efficiency effects of universal-type integration. One study of universal banks in Europe found that they typically had both higher revenues and higher profitability than specializing institutions (Vander Vennet 1999). Some simulation-type studies combined the rates of return earned by different categories of U.S. institutions with mixed results (e.g., Boyd, Graham, and Hewitt 1993, Saunders and Walter 1994). Other studies of actual combinations of banking and insurance in the U.K. (Llewellyn 1996) and banking and securities firms in the U.S. (Kwan 1998) showed favorable results.

As was the case for cost scope efficiency, some inference about the revenue efficiency effects of universal-type operations may be taken from the research that uses data from firms producing multiple products within a single category of financial services. One study of revenue scope efficiency in the banking industry found little or no revenue scope efficiency between deposits and loans in terms of charging customers for joint consumption benefits (Berger, Humphrey, and Pulley 1996). One study in the insurance industry found revenue scope diseconomies from providing life insurance and property-liability insurance together, consistent with a greater ability of specialists to tailor products to their customers' needs (Berger, Cummins, Weiss, and Zi 2000). One profit scope efficiency study of banking (Berger, Hancock, and Humphrey 1993) and one study of insurance (Berger, Cummins, Weiss, and $\mathrm{Zi} \mathrm{2000)} \mathrm{found} \mathrm{that} \mathrm{joint} \mathrm{production} \mathrm{is} \mathrm{more} \mathrm{efficient} \mathrm{for} \mathrm{some} \mathrm{firms} \mathrm{and}$ specialization is more efficient for others.

Again, it is not known how well the research on scope efficiencies within a category of financial institution represents efficiencies across institution categories. We suspect that revenue scope efficiency effects would be more favorable for universal-type integration than integration within a category of financial services because the correlations of returns across industries is generally much lower than the returns within one industry, providing better opportunities to diversify risks. However, as noted above, organizational problems in managing firms in industries outside the core competence of senior managers could offset this advantage of cross-industry integration. Overall, the research on revenue scope efficiency suggests that there may be modest revenue gains 
from the integration of the providers of different categories of financial services into universal-type organizations, although more research is needed.

\section{The efficiency effects of the international consolidation of financial service providers}

The international consolidation of financial institutions typically involves scale, geographic, and international integration, and may also involve scope integration as well, as so may involve any or all of the scale, scope, and X-efficiency effects described in the prior sections. However, there are some additional factors that may make international consolidation have very different efficiency consequences than consolidation among two institutions within a single nation.

First, there may be some barriers that inhibit foreign financial institutions from operating efficiently and competing against domestic institutions. These barriers may include differences in language, culture, currency, and regulatory/supervisory structures, and explicit or implicit rules against foreign competitors. In addition, institutions in different nations are typically located at significant distances from one another, which may be associated with organizational diseconomies to operating or monitoring from a distance, as discussed above regarding cross-regional activity. If these barriers are sufficiently high, they may reduce the efficiency of foreignowned institutions and prevent substantial international consolidation. If these barriers are sufficiently low, efficiently managed foreign institutions may often be able to overcome them and operate relatively efficiently in many nations.

Importantly, these barriers to efficient international integration can be modified significantly by government policy. For example, the EU's Single Market Programme and European Monetary Union may be interpreted as reducing the efficiency barriers to cross-border consolidation within the EU, and within the subset participating in monetary union, respectively. These policies reduce or eliminate differences in currency, regulatory/supervisory structures, and explicit rules against foreign competitors from other EU nations. However, these actions may not lower other barriers, such as differences in language and culture, implicit rules against foreign institutions, and distances between nations.

Second, we expect the improvements to cost and revenue efficiency associated with risk diversification to be substantially greater on average for cross-border consolidation than within-nation consolidation. This is because nations differ greatly in their macroeconomic cycles, monetary and fiscal policies, prudential 
regulation/supervision, etc., and because nations have trade and investment barriers that reduce the flows of resources that would otherwise tend to equilibrate rates of return in different nations. Some empirical evidence is consistent with this expectation — one found the correlations of bank earnings across major developed nations to be considerably lower than cross-regional correlations in the U.S. (Berger, DeYoung, Genay, and Udell 2000). The international correlations were very low and often negative, even across nations in the EU, which has moved towards a "single market."

Third, there may be additional revenue X-efficiency effects from cross-border consolidation because it allows the institution to serve customers that operate in multiple nations. Multinational customers often require or benefit from the services of financial institutions that operate in the same set of nations, and may be willing to pay more for doing business with multinational financial institutions. Part of this revenue X-efficiency comes from financial institutions following their existing customers across international borders, maintaining the benefits of existing relationships, and some analysis of foreign banks in the U.S. is consistent with this hypothesis (e.g., Goldberg and Saunders 1981, Terrell 1993, Goldberg and Grosse 1994).

Fourth, cross-border efficiency may be affected by the market conditions and policies of the home nation. Some nations may have specific favorable market or regulatory/supervisory conditions at home that allow institutions headquartered there to operate efficiently in other nations. Home country favorable market conditions may include stiff product market competition that provides a proving ground for efficient organizations, an active market for corporate control that prevents cross-border consolidation that reduces shareholder value, access to a well-developed securities market that allows for exploitation of scope efficiencies, or access to an educated labor force. Favorable regulatory/supervisory conditions may include access to universal banking powers, relaxed prudential regulation or supervision or strong safety net guarantees that allow the organizations to undertake high risk-high expected return financial strategies. Alternatively, relatively tough home supervision/regulation may give some institutions cross-border advantages by certifying their quality or reducing the risks of their contractual counterparties.

The main research subjects covered here are the international comparisons of financial institution cost and profit X-efficiency (subsection 6.1) and the cost and profit X-efficiencies of foreign versus domestic institutions within a single nation (subsection 6.2). These may give information as to whether certain nations have 
efficiency advantages and whether institutions can overcome the efficiency barriers and operate efficiently as internationally integrated financial institutions.

\subsection{International comparisons of cost and profit X-efficiency}

A number of studies compared the average X-efficiency of institutions in different nations, focusing on the operations of institutions operating within each nation, rather than cross-border operations (e.g., Berg, Forsund, Hjalmarsson, and Suominen 1993, Allen and Rai 1996, Ruthenberg and Elias 1996, Pastor, Perez, and Quesada, 1997, Dietsch and Lozano-Vivas forthcoming). The results often showed that some institutions of some nations are substantially more efficient than the institutions of other nations, although the ordering among nations sometimes differed across the studies. In some cases, the results ran contrary to expectations. For example, U.S. banks were sometimes measured as inferior performers, despite the common result (discussed below) that U.S. banks tend to be more efficient than foreign competitors in the U.S.

While these studies are informative, they may not be very helpful for evaluating the efficiency effects of international consolidation for two main reasons. First, the economic environments faced by financial institutions

differ across nations in important ways. Second, even if all of the environmental differences could be controlled for, the performance of institutions within their own borders may not be representative of how well they may perform as foreign-owned entities in other nations. Even institutions that are very efficient at home may have difficulty in other nations because of the cross-border efficiency barriers discussed above (language, culture, currency, regulatory/supervisory structures, explicit or implicit rules, distance).

\subsection{The cost and profit $\mathrm{X}$-efficiency of foreign versus domestic institutions within a single nation}

Some studies have compared the X-efficiencies of foreign versus domestic institutions operating within the borders of a single country. This avoids the econometric problem of controlling for environmental differences across nations, since all of the institutions studied face essentially the same environmental conditions. More important, this is direct evidence on the extent to which financial institutions are able to operate or monitor subsidiaries efficiently on a cross-border basis, which is critical to determining whether international integration is successful in increasing efficiency. Note, however, that any efficiency benefits or costs of cross-border operations that are realized in the headquarters of the international organizations are not measured by the performance of their foreign affiliates. 
Studies of U.S. data generally found that foreign-owned banks are significantly less cost efficient and profit efficient on average than domestic banks (e.g., DeYoung and Nolle 1996, Mahajan, Rangan, and Zardkoohi 1996). Unfortunately, this type of evidence alone cannot distinguish all of the alternative hypotheses. The data are consistent with the possibilities that 1) foreign institutions generally have lower efficiency than domestic institutions in general; 2) U.S. institutions are more efficient than institutions from other nations; and 3) foreign banks from some other nations are more efficient and some are less efficient than domestic U.S. banks, but the averages mask differences among nations of foreign ownership. More evidence is needed to differentiate among these alternatives - data from more home countries and disaggregation of the results by nation of foreign ownership.

Some research on other nations found that foreign institutions have about the same average efficiency as domestic institutions (e.g., Vander Vennet 1996, Hasan and Lozano-Vivas 1998, Bhattacharya, Lovell, and Sahay 1997, Cummins and Rubio-Misas 1999), although there were sometimes differences by the type of ownership (stock, mutual, government). Again, the results were not disaggregated by foreign nation of origin, making it difficult to determine whether institutions from some nations tend to be more efficient when they operate across borders.

Other research measured profit efficiency for a number of home countries, classified by banking system development and regulatory/supervisory environment (Miller and Parkhe 1999, Parkhe and Miller 1999). They found that domestic banks were more efficient on average than foreign institutions (including U.S.- owned banks), although foreign banks from the same type of environment as the host nation generally fared better than other foreign institutions. Although they appropriately measured separate frontiers for the institutions located in each country, they normalized and pooled the efficiency estimates from the foreign and domestic banks in the several nations in each group, which may create problems of comparison because of the different environments of these nations.

Finally, one study addressed some of the methodological drawbacks in the literature by 1) examining cost and profit $\mathrm{X}$-efficiency in a number of home countries, 2) by distinguishing among nations of origin of foreign institutions, and 3) by conducting completely separate analyses of data from banks located in different countries (Berger, DeYoung, Genay, and Udell 2000). They used data from five home countries - France, Germany, 
Spain, the UK, and the U.S. Consistent with most of the literature, they found that domestic banks usually had higher mean profit X-efficiency than the mean of all foreign banks operating in that country.

Disaggregation of the results by foreign nation of origin suggested two additional conclusions. First, in most EU nations, there was very little penetration by foreign banks headquartered in other EU nations, and those that did penetrate typically had slightly lower efficiency on average than domestic banks. This suggests that at least for their time period (1992-1997), barriers to cross-border operating efficiency offset most of any potential efficiency gains in the EU, despite the Single Market Programme. Second, institutions headquartered in the U.S. tended to be more efficient than other institutions both at home and in other nations, suggesting that some (unknown) favorable market or regulatory/supervisory conditions in the U.S. may allow its banks to be relatively efficient. Most of the efficiency advantage of U.S. institutions was on the revenue side of the income statement, rather than the cost side.

\section{Summary of the research findings and directions for future research}

The evidence reviewed here suggests that the integration of the financial services industry is continuing, and perhaps accelerating in a number of dimensions due in large part to regulatory changes and market reactions to these changes. We review the research evidence on the efficiency effects of three important complex types of integration, 1) national consolidation within a single product category; 2) integration of multiple categories of services into universal-type organizations; and 3) consolidation across international borders. These three types fit into our proposed working definition of financial services industry integration as events that join two or more financial service organizations or combine two or more dimensions of the production or distribution of financial services.

In the remainder of our discussion, we review the findings on the potential for efficiency gains from integration (subsection 7.1), and summarize the actual efficiency improvements found or predicted by the extant literature (subsection 7.2). We then reorganize the research results into the efficiency implications or predictions from our three main types of integration (subsection 7.3). Finally, we suggest directions for future research (subsection 7.4).

\subsection{The potential for efficiency gains from integration}

The research findings reviewed here suggest that there is a large potential for improvements in 
efficiency from financial integration. Looking first at costs, the potential to improve X-efficiency is clear. Cost X-efficiency was found to be on the order of $80 \%$ on average, implying that about $20 \%$ of costs were lost due to $\mathrm{X}$-inefficiency. Much of the integration activity is M\&As in which more cost X-efficient acquirers take over less cost X-efficient targets, creating the potential for large cost efficiency gains if the acquiring organizations can effectively spread their superior skills over more resources. The M\&A process itself may also improve Xefficiency by awakening management to the need for improvement or by being used as an excuse to implement unpleasant restructuring. Cost X-efficiency may also be improved if the integration diversifies risks, reducing the cost of capital or lowering the costs of complying with prudential regulation/supervision. The potential for cost $\mathrm{X}$-efficiency losses is also substantial if integration spreads inferior managerial practices or creates substantial operational disruptions.

The research is less clear about the potential for cost scale and scope efficiency gains from integration. Most of the research suggests very little potential cost efficiency gains from greater scale except at very small sizes. We acknowledge the lack of direct research evidence on the scope efficiency effects of universal-type integration. The limited evidence does not suggest strong potential scope efficiency gains associated with universal-type integration. It might be expected that these gains, if any, would be smaller than the scale and scope efficiency gains from integration within a product category because the shared inputs are less similar and because the organizational diseconomies of operating or monitoring a universal-type organization are likely to be worse than those in a single-category organization. However, there is a possibility of increased scale and scope economies or fewer organizational diseconomies due to new financial, information, and communications technologies, and there is some limited evidence of these increased economies.

The research findings also strongly suggest large potentials for revenue and profit efficiency gains from financial integration. Profit X-efficiency was typically found to be on the order of $50 \%$ on average, implying that about half of financial institution potential profits were lost due to X-inefficiency. Most M\&As appear to be the type that might bring about significant profit efficiency gains - more profit X-efficient acquirers taking over less profit X-efficient targets. The extant research suggests the potential revenue efficiency benefits from improved risk diversification may be particularly large. Much of the measured profit X-efficiency benefits from bank consolidation in the U.S. appeared to be generated by improvements in risk diversification that allowed 
institutions to switch into higher risk-higher expected return portfolios. The potential for such benefits from universal-type and international integration would be expected to be even larger, since correlations of earnings across categories and across international borders are lower than those across institutions of the same type in a single country.

\subsection{The actual efficiency improvements from integration}

The research also suggests that actual cost efficiency gains from any of our three types of integration are likely to be small by comparison with the potential. The data on national integration within a single product category suggest that organizational diseconomies of operating the larger or more far-flung enterprises or disruptions from the M\&A process offset most of the potential cost efficiency gains. There is less evidence on universal-type and international integration, but the limited data are consistent with the likelihood that the organizational diseconomies of operating and monitoring these organizations would be worse and the cost efficiency gains less than for national integration within a category.

The research findings generally suggest that integration brings about larger revenue efficiency gains than cost efficiency gains. Most of these gains appear to be from the benefits of risk diversification that allows the institutions the opportunity to make higher risk-higher expected return investments. Most of these results are drawn from studies of national integration within a product category in the U.S. It seems likely that the gains from risk diversification are higher for universal-type and international-type integration, given the simulation and correlation evidence. However, the organizational diseconomies from operating institutions providing multiple categories of financial services or problems in confronting the barriers to efficient cross-border operations may offset much of the risk diversification gains for these types of integration.

\subsection{The efficiency effects of our three complex types of integration}

At the cost of some repetition, we briefly reorganize our summary of the efficiency effects of integration along the lines of our three complex types of financial integration. With regard to the national consolidation of financial institutions within a single product category, there may be modest X-efficiency gains, primarily on the revenue side. Geographic integration across regions appears to improve the risk-expected return tradeoff faced by financial institutions because of relatively low or negative correlations of returns in different regions. There appear to be revenue X-efficiency gains associated with the cross-regional ownership of large institutions, 
although there may be X-efficiency losses associated with the cross-regional ownership of small institutions. In addition, there may be revenue $\mathrm{X}$-efficiency gains associated with the M\&A process as acquirers appear to choose targets that diversify risks, and take advantage of this with higher risk-higher expected return investments. There may also be some scale and scope efficiency gains associated with recently implemented technology, but these are not yet firmly demonstrated.

With regard to the integration of multiple categories of services into universal-type organizations, all of the efficiency gains just discussed for national consolidation within a single product category may apply here as well. In addition, we expect more substantial revenue efficiency gains from this consolidation through diversification gains, given the relatively low correlations between earnings in the different financial service lines. There may also be revenue efficiency gains from providing customers with "one-stop shopping" convenience, although some limited evidence suggests that customers may prefer to purchase from specialists that have better knowledge and expertise in their areas of core competence and can better tailor products for individual customers. In addition, there may be fewer cost scope economies or more diseconomies associated with universal-type integration because of organizational diseconomies from operating institutions providing multiple categories of financial services. However, these results must be viewed with more caution because the available efficiency research on universal organizations is very thin and has to be augmented with the results of other research.

With regard to the consolidation of financial institutions across international borders, all of the efficiency effects found for national within-category and universal-type integration may apply to cross-border consolidation of the within-category and universal types, respectively. However, there are also several reasons to expect that cross-border efficiency consequences may differ, including a number of efficiency barriers (language, culture, currency, regulatory/supervisory structures, explicit or implicit rules, distance); greater benefits from risk diversification and serving multinational customers; and home nation market and regulatory/supervisory advantages that may be transferred abroad. The research findings suggest that some types of cross-border operations may improve X-efficiency, primarily on the revenue side of the income statement. However, the gains appear to be somewhat limited by the cross-border efficiency barriers - in most cases foreign-owned banks are less efficient on average than domestic banks. The findings also suggest that some organizations overcome these barriers and operate with relatively high efficiency both at home and abroad, particularly some U.S.-based 
organizations, possibly reflecting favorable home country conditions. The cross-border efficiency results should be viewed with caution, given that so few studies break out the cross-border efficiency results by home nation and nation of origin of the foreign institutions.

\subsection{Directions for future research}

There remains much research to be done on the efficiency effects of the integration of the financial services industry. The available research is limited and often requires a considerable amount of extrapolation to draw meaningful conclusions. The most glaring areas where research is lacking are 1) basic efficiency research on the securities and insurance industries and for non-U.S. financial service providers, 2) research on the scope and X-efficiency effects of universal-type integration, and 3) research on the efficiency effects of international integration.

In addition, given the perhaps surprising findings that most of the efficiency gains from integration appear to be on the revenue side and appear to be related to risk diversification, it is important to focus on these and other sources of efficiency gains in future research. As part of this focus, observations are needed on how portfolio mixes change after M\&As to determine whether the institutions switch into higher risk-higher expected return investments.

As well, further research using recent data is be needed on the scale and scope efficiency of financial institutions. Recent changes in technology and financial instruments may have increased the scale and scope at which financial institutions are most efficient.

Finally, we suggest research on several unknown underlying causes of efficiency effects of integration. In particular, we suggest additional research on what underlies 1) the efficiency effects of the M\&A process itself (e.g., which types of M\&As are most likely to improve efficiency?), 2) the efficiency effects of geographic integration (e.g., are the policies and procedures used in distant subsidiaries the same as the headquarters institution?), and 3) the efficiency effects of international integration (e.g., what are the individual effects of the different cross-border efficiency barriers?; what conditions allow some institutions to operate more efficiently than institutions headquartered in other nations?). 


\section{$\underline{\text { References }}$}

Akhavein, Jalal D., Allen N. Berger, and David B. Humphrey. 1997. "The Effects of Bank Megamergers on Efficiency and Prices: Evidence from the Profit Function.” Review of Industrial Organization 12: 95139.

Allen, Linda and Anoop Rai. 1996. “Operational Efficiency in Banking: An International Comparison.” Journal of Banking and Finance 20: 655-672.

Bauer, Paul W., and Gary D. Ferrier. 1996. "Efficiency Measurement Issues for Payments Processing.” Journal of Money, Credit and Banking 28(4): 1004-1039.

Bauer, Paul W., and Diana Hancock. 1993. "The Efficiency of the Federal Reserve in Providing Check Processing Services." Journal of Banking and Finance 17(3): 287-311.

Benston, George J., William C. Hunter, and Larry D. Wall. 1995. "Motivations for Bank Mergers and Acquisitions: Enhancing the Deposit Insurance Put Option Versus Earnings Diversification.” Journal of Money, Credit, and Banking 27(3): 777-788.

Berg, Sigbjorn Atle, Finn Forsund, Lennart Hjalmarsson, and Matti Suominen. 1993. "Banking Efficiency in the Nordic Countries." Journal of Banking and Finance 17: 371-388.

Berger, Allen N. 1995. "The Relationship Between Capital and Earnings in Banking." Journal of Money, Credit and Banking 27(2): 432-456.

Berger, Allen N. 1998. "The Efficiency Effects of Bank Mergers and Acquisition: A Preliminary Look at the 1990s Data." In Bank Mergers \& Acquisitions, edited by Y. Amihud and G. Miller. Boston, MA. Kluwer Academic: 79-111.

Berger, Allen N., J. David Cummins, Mary A. Weiss. 1997. "The Coexistence of Multiple Distribution Systems for Financial Services: The Case of Property-Liability Insurance.” Journal of Business 70(4): 515-546.

Berger, Allen N., J. David Cummins, Mary A. Weiss, and Hongmin Zi. 2000. "Conglomeration Versus Strategic Focus: Evidence from the Insurance Industry.” Board of Governors of the Federal Reserve System.

Berger, Allen N., Rebecca S. Demsetz, and Philip E. Strahan. 1999. "The Consolidation of the Financial Services Industry: Causes, Consequences, and Implications for the Future.” Journal of Banking and Finance 23 (2-4): 135-194.

Berger, Allen N., and Robert DeYoung. 2000. "The Financial Performance of Cross-Regional Commercial Banks in the U.S.: Some Clues Regarding the Eventual Structure of a Consolidating Industry.” Board of Governors of the Federal Reserve System.

Berger, Allen N., Robert DeYoung, Hesna Genay, and Gregory F. Udell. 2000. "The Globalization of Financial Institutions: Evidence from Cross-Border Banking Performance." Brookings-Wharton Papers on Financial Services 3.

Berger, Allen N., Diana Hancock, and David B. Humphrey. 1993. "Bank Efficiency Derived from the Profit Function." Journal of Banking and Finance 17(2-3): 317-347. 
Berger, Allen N., Gerald A. Hanweck, and David B. Humphrey. 1987. "Competitive Viability in Banking: Scale, Scope, and Product Mix Economies.” Journal of Monetary Economics 20(3): 501-520.

Berger, Allen N., and David B. Humphrey. 1992. "Megamergers in Banking and the Use of Cost Efficiency as an Antitrust Defense.” Antitrust Bulletin, 37 (Fall), 541-600.

Berger, Allen N., and David B. Humphrey. 1997. "Efficiency of Financial Institutions: International Survey and Directions for Future Research.” European Journal of Operational Research 98: 175-212.

Berger, Allen N., David B. Humphrey, and Lawrence B. Pulley. 1996. "Do Consumers Pay for One-Stop Banking? Evidence from an Alternative Revenue Function." Journal of Banking and Finance 20(9): 1601-1621.

Berger, Allen N., John H. Leusner, and John J. Mingo. 1997. “The Efficiency of Bank Branches.” Journal of Monetary Economics 40(1): 141-162.

Berger, Allen N., and Loretta J. Mester. 1997. "Inside the Black Box: What Explains Differences in the Efficiencies of Financial Institutions?" Journal of Banking and Finance 21: 895-947.

Berger, Allen N., and Loretta J. Mester. 1999. "What Explains the Dramatic Changes in Cost and Profit Performance of the U.S. Banking Industry?" Board of Governors of the Federal Reserve System.

Bhattacharya, Amar, C. A. Knox Lovell, and P. Sahay. 1997. "The Impact of Liberalization on the Productive Efficiency of Indian Commercial Banks.” European Journal of Operational Research 98: 332-345.

Borch, Karl.1962. "Equilibrium in a Reinsurance Market.” Econometrica 30: 424-444.

Boyd, John H., Stanley L. Graham, and R. Shawn Hewitt. 1993. "Bank Holding Company Mergers with Nonbank Financial Firms: Effects on the Risk of Failure." Journal of Banking and Finance 17(1): 4363.

Clark, Jeffrey and Thomas F. Siems. 1997. "Competitive Viability in Banking: Looking Beyond the Balance Sheet.” Federal Reserve Bank of Dallas, Financial Industry Studies Working Paper No. 5-97.

Cornett, Marcia Millon, and Hassan Tehranian. 1992. "Changes in Corporate Performance Associated with Bank Acquisitions.” Journal of Financial Economics 31(2): 211-234.

Cummins, J. David, 2000. "Efficiency in the U.S. Life Insurance Industry: Are Insurers Minimizing Costs and Maximizing Revenues?" in J.D. Cummins and A.M. Santomero, eds., Changes in the Life Insurance Industry: Efficiency, Technology, and Risk Management. Norwell, MA: Kluwer Academic Publishers, pp. $75-115$

Cummins, J. David, Neil A. Doherty, and Anita Lo. 1999. "Can Insurers Pay For The "Big One"? Measuring The Capacity of the Insurance Market to Respond to Catastrophic Losses." Wharton Financial Institutions Center, Philadelphia.

Cummins, J. David and Maria Rubio-Misas. 1999. "Efficiency in the Spanish Insurance Industry," working paper, Wharton Financial Institutions Center, University of Pennsylvania, Philadelphia.

Cummins, J. David, Sharon L. Tennyson, and Mary A. Weiss. 1999. "Consolidation and Efficiency in the US 
Life Insurance Industry.” Journal of Banking and Finance 23(2-4): 325-357.

Cummins, J. David, and Mary A. Weiss. 2000a. "Analyzing Firm Performance in the Insurance Industry Using Frontier Efficiency Methods." in Georges Dionne, ed., Handbook of Insurance Economics Norwell, MA: Kluwer Academic Publishers, in press.

Cummins, J. David, and Mary A. Weiss. 2000b. "The Global Market for Reinsurance: Consolidation, Capacity, and Efficiency." Brookings-Wharton Papers on Financial Services 3.

Cummins, J. David, and Hongmin Zi. 1998. "Comparison of Frontier Efficiency Methods: An Application to the U.S. Life Insurance Industry.” Journal of Productivity Analysis 10(2): 131-152.

Cybo-Ottone, Alberto, and Maurizio Murgia. 1998. "Mergers and Shareholder Wealth in European Banking." Associazione Bancaria Italiana.

DeLong, Gayle L. 1999. "Domestic and International Bank Mergers: Shareholder Gains from Focusing versus Diversifying.” Baruch College.

DeLong, Gayle L., Roy C. Smith, and Ingo Walter. 1998. "Global Merger and Acquisition Tables 1997." Solomon Center, New York University.

Demsetz, Rebecca S. and Phillip E. Strahan. 1997. "Diversification, Size, and Risk at Bank Holding Companies." Journal of Money, Credit, and Banking 29(3): 300-13.

DeYoung, Robert. 1997. "Bank Mergers, X-Efficiency, and the Market for Corporate Control.” Managerial Finance 23: 32-47.

DeYoung, Robert, and Daniel E. Nolle. 1996. "Foreign-Owned Banks in the U.S.: Earning Market Share or Buying It?" Journal of Money, Credit, and Banking 28(4): 622-636.

Dietsch, Michel, and Ana Lozano-Vivas. forthcoming "How the Environment Determines Banking Efficiency: A Comparison between French and Spanish Industries." Journal of Banking and Finance.

Fried, Harold O., C. A. Knox Lovell, and Suthathip Yaisawarng. 1999. "The Impact of Mergers on Credit Union Service Provision.” Journal of Banking and Finance 23(2-4): 367-86.

Gande, Amar, Manju Puri, Anthony Saunders, and Ingo Walter. 1997. "Bank Underwriting of Debt Securities: Modern Evidence.” The Review of Financial Studies 10(4): 1175-1202.

Gardner, Lisa and Martin F. Grace. 1993. "X-Efficiency in the U.S. Life Insurance Industry." Journal of Banking and Finance 17(2-3): 497-510.

Goldberg, Lawrence G. and Robert Grosse. 1994. "Location Choice of Foreign Banks in the United States." Journal of Economics and Business 46, 367-379.

Goldberg, Lawrence G., Gerald A. Hanweck, Michael Keenan, and Allister Young. 1991. "Economics of Scale and Scope in the Securities Industry." Journal of Banking and Finance 15: 91-107.

Goldberg, Lawrence G. and Anthony Saunders. 1981. "The Determinants of Foreign Banking Activity in the United States." Journal of Banking and Finance 5: 17-32. 
Hancock, Diana, David B. Humphrey, and James A. Wilcox. 1999. "Cost Reductions in Electronic Payments: The Roles of Consolidation, Economies of Scale, and Technical Change." Journal of Banking and Finance 23(2-4): 391-421.

Hannan, Timothy H. and John D. Wolken. 1989. "Returns to Bidders and Targets in the Acquisition Process: Evidence from the Banking Industry.” Journal of Financial Services Research 3(1): 5-16.

Hasan, Iftekhar and Ana Lozano-Vivas. 1998. "Foreign Banks, Production Technology, and Efficiency: Spanish Experience." Working Paper presented at the Georgia Productivity Workshop III, Athens, Georgia.

Haynes, Michael and S. Thompson. 1999. "The Productivity Effects Of Bank Mergers: Evidence From The UK Building Societies." Journal of Banking and Finance 23: 325-846.

Houston, Joel F., and Michael D. Ryngaert. 1994. "The Overall Gains from Large Bank Mergers.” Journal of Banking and Finance 18(6): 1155-76.

Houston, Joel F., and Michael D. Ryngaert. 1997. "Equity Issuance and Adverse Selection: A Direct Test Using Conditional Stock Offers.” Journal of Finance 52(1): 197-219.

Hughes, Joseph P., William Lang, Loretta J. Mester, and C. G. Moon. 1996. "Efficient Banking Under Interstate Branching." Journal of Money, Credit, and Banking 28(4): 1043-1071.

Hughes, Joseph P., William Lang, Loretta J. Mester, and C. G. Moon. 1999. "The Dollars and Sense of Bank Consolidation.” Journal of Banking and Finance 23(2-4): 291-324.

Hughes, Joseph P. and Loretta J. Mester. 1998. "Bank Capitalization and Cost: Evidence of Scale Economies in Risk Management and Signaling.” Review of Economics and Statistics 80(2): 314-325.

Hunter, William C., Stephen G. Timme, and Won Keun Yang. 1990. "An Examination of Cost Subadditivity and Multiproduct Production in Large U.S. Banks.” Journal of Money, Credit and Banking 22(4): 504-525.

Kroszner, Randall S. and Raghuram G. Rajan. 1997. "Organizational Structure and Credibility: Evidence from Commercial Bank Securities Activities before the Glass-Steagall Act.” Journal of Monetary Economics 39: 475-516.

Kwan, Simon 1998. “Securities Activities by Commercial Banking Firms' Section 20 Subsidiaries: Risk, Return, and Diversification Benefits." Federal Reserve Bank of San Francisco (October).

Lang, Gunter and Peter Welzel. 1998. "Technology and Cost Efficiency in Universal Banking: A Thick Frontier Approach.” Journal of Productivity Analysis 10(1): 63-84.

Mahajan, Arvind, Nanda Rangan, and Asghar Zardkoohi. 1996. "Cost Structures in Multinational and Domestic Banking." Journal of Banking and Finance 20(2): 238-306.

McAllister, Patrick H., and Douglas A. McManus. 1993. "Resolving the Scale Efficiency Puzzle in Banking." Journal of Banking and Finance 17(2-3): 389-405.

Miller, Stewart R. and Arvind Parkhe. 1999. "Home-Country Environment as a Source of International Competitiveness: An Analysis of the Global Banking Industry.” Michigan State University. 
Noulas, Athanasios G., Stephen M. Miller, and Subhash C. Ray. 1993. "Regularity Conditions and Scope Estimates: The Case of Large-Sized U.S. Banks.” Journal of Financial Services Research 7(3): 235-48.

Noulas, Athanasios G., Subhash C. Ray, and Stephen M. Miller. 1990. "Returns to Scale and Input Substitution for Large U.S. Banks.” Journal of Money, Credit, and Banking 22(1): 94-108.

Parkhe, Arvind and Stewart R. Miller. 1999. "Is There a Liability of Foreignness in Global Banking? An Empirical Test of U.S. Banks' X-Efficiency.” Michigan State University.

Pastor, Jose Manuel., Francisco Perez, and Javier Quesada. 1997. "Efficiency Analysis in Banking Firms: An International Comparison.” European Journal of Operational Research 98: 396-408.

Peristiani, Stavros. 1997. "Do Mergers Improve the X-efficiency and Scale Efficiency of U.S. banks? Evidence from the 1980s." Journal of Money, Credit, and Banking 29(3): 326-337.

Pilloff, Steven J. 1996. "Performance Changes and Shareholder Wealth Creation Associated with Mergers of Publicly Traded Banking Institutions.” Journal of Money, Credit, and Banking 28(3): 294-310.

Puri, Manju. 1996. "Commercial Banks in Investment Banking: Conflict of Interest or Certification Role?" Journal of Financial Economics 40(3): 373-401.

Radecki, Lawrence J., J. Wenninger, and D.K. Orlow. 1997. "Industry Structure: Electronic Delivery's Potential Effects on Retail Banking." Journal of Retail Banking Services 19(4): 57-63.

Resti, Andrea. 1998. "Regulation Can Foster Mergers, Can Mergers Foster Efficiency? The Italian Case." Journal of Economics and Business 50(2): 157-169.

Rhoades, Stephen A. 1998. "The Efficiency Effects of Bank Mergers: An Overview of Case Studies of Nine Mergers.” Journal of Banking and Finance 22(3): 273-291.

Ruthenberg, D. and R. Elias. 1996. "Cost Economies and Interest Rate Margins in a Unified European Banking Market." Journal of Economics and Business 48: 231-249.

Saunders, Anthony and Ingo Walter. 1994. Universal Banking in the United States. Oxford: Oxford University Press.

Shaffer, Sherrill. 1993. "Can Megamergers Improve Bank Efficiency?” Journal of Banking and Finance 17: 423-436.

Smith, Randall and Charles Gasparino. 2000. "Solomon's Gains are Registering as part of Citi's Supermarket." Wall Street Journal (March 2, 2000): C1, C2.

Terrell, Henry S. 1993. "U.S. Branches and Agencies of Foreign Banks: A New Look." Federal Reserve Bulletin 79 (October): 913-925.

van Beek, Luuk and Alireza Tourani Rad. 1997. "Market Valuation of Bank Mergers in Europe" Financial Services. Amsterdam. 
Vander Vennet, Rudi. 1996. "The Effect of Mergers and Acquisitions on the Efficiency and Profitability of EC Credit Institutions.” Journal of Banking and Finance 20(9): 1531-1558.

Vander Vennet, Rudi. 1999. "Cost and Profit Dynamics in Financial Conglomerates and Universal Banks in Europe." University of Ghent. Belgium.

Winton, Andrew. 1999. "Don't Put All Your Eggs in One Basket? Diversification and Specialization in Lending." University of Minnesota.

Yuengert, Andrew. 1993. "The Measurement of Efficiency in Life Insurance: Estimates of a Mixed NormalGamma Error Model.” Journal of Banking and Finance 17(2-3): 483-496.

Zhang, Hao. 1995. "Wealth Effects of U.S. Bank Takeovers." Applied Financial Economics 5(5): 329-336. 
Table 1

$\underline{\text { Simple Types of Financial Services Industry Integration }}$

\begin{tabular}{|c|c|}
\hline Simple Type of Integration & Example \\
\hline 1. Scale integration. & M\&As of similar organizations. \\
\hline 2. Scope integration. & M\&As among commercial banks, investment banks, and insurers. \\
\hline 3. Geographic integration. & Cross-regional M\&As of regional providers. \\
\hline 4. International integration. & Cross-border M\&As of organizations of national providers. \\
\hline 5. Horizontal integration of distribution systems. & Offer "one-stop shopping" for multiple services in a single location. \\
\hline 6. Horizontal integration of production systems. & Share information in underwriting loans, securities, and insurance. \\
\hline 7. Vertical integration of production and distribution systems. & Underwriter shifts from independent agents to direct distribution of services. \\
\hline
\end{tabular}


Table 2

\section{Complex Types of Financial Services Industry Integration Reviewed Here}

\begin{tabular}{|c|c|c|}
\hline Complex Type of Integration & Corresponding Simple Types of Integration & Research Subjects Reviewed \\
\hline $\begin{array}{l}\text { 1. National integration of financial institutions within } \\
\text { a single product category (e.g., M\&A of two } \\
\text { commercial banks, two securities firms, or two } \\
\text { insurers). }\end{array}$ & $\begin{array}{l}\text { Scale integration. } \\
\text { May also involve geographic integration. }\end{array}$ & $\begin{array}{l}\text { Cost and revenue scale efficiency of financial institutions. } \\
\text { Cost and profit X-efficiency effects of geographic integration. } \\
\text { Dynamic effects of the M\&A process on cost and profit X- } \\
\text { efficiency. }\end{array}$ \\
\hline $\begin{array}{l}\text { 2. Integration of different categories of financial } \\
\text { services into universal-type organizations (e.g., } \\
\text { M\&As among banks, securities firms, and/or } \\
\text { insurers). }\end{array}$ & $\begin{array}{l}\text { Scale and scope integration. } \\
\text { May also involve geographic and international } \\
\text { integration. }\end{array}$ & $\begin{array}{l}\text { Cost and revenue scope efficiency effects of universal-type } \\
\text { integration. } \\
\text { (Much of this is drawn from scope efficiency studies within } \\
\text { one category of financial services and from simulations of the } \\
\text { risk diversification benefits of universal-type integration). }\end{array}$ \\
\hline $\begin{array}{l}\text { 3. International integration of financial institutions } \\
\text { (e.g., cross-border M\&As). }\end{array}$ & $\begin{array}{l}\text { Scale, geographic, and international integration. } \\
\text { May also involve scope integration. }\end{array}$ & $\begin{array}{l}\text { International comparisons of } \mathrm{X} \text {-efficiency. } \\
\mathrm{X} \text {-efficiencies of foreign versus domestic institutions within a } \\
\text { single nation. }\end{array}$ \\
\hline
\end{tabular}


Table 3

\section{Values of Target Institutions in M\&A Activity in Financial Services from 1985-1997}

Panel A: Domestic M\&As

Target Institution

U.S. $\quad$ Europe

\begin{tabular}{|c|c|c|c|c|c|c|}
\hline & & & & & & \\
\hline $\begin{array}{l}\text { Acquiring } \\
\text { Institution }\end{array}$ & Banks & Securities & Insurance & Banks & Securities & Insurance \\
\hline $\begin{array}{l}\text { Commercial } \\
\text { Banks }\end{array}$ & $\begin{array}{c}241 \\
(51.8 \%)\end{array}$ & $\begin{array}{c}15 \\
(3.2 \%)\end{array}$ & $\begin{array}{c}0.2 \\
(0.1 \%)\end{array}$ & $\begin{array}{c}89 \\
(36.0 \%)\end{array}$ & $\begin{array}{c}9 \\
(3.6 \%)\end{array}$ & $\begin{array}{c}20 \\
(8.1 \%)\end{array}$ \\
\hline $\begin{array}{l}\text { Securities } \\
\text { Firms }\end{array}$ & $\begin{array}{c}6 \\
(1.2 \%)\end{array}$ & $\begin{array}{c}74 \\
(15.9 \%)\end{array}$ & $\begin{array}{c}27 \\
(5.8 \%)\end{array}$ & $\begin{array}{c}23 \\
(9.3 \%)\end{array}$ & $\begin{array}{c}19 \\
(7.7 \%)\end{array}$ & $\begin{array}{c}24 \\
(9.7 \%)\end{array}$ \\
\hline $\begin{array}{l}\text { Insurance } \\
\text { Companies }\end{array}$ & $\begin{array}{c}0.3 \\
(0.1 \%)\end{array}$ & $\begin{array}{c}14 \\
(3.0 \%)\end{array}$ & $\begin{array}{c}88 \\
(18.9 \%)\end{array}$ & $\begin{array}{c}11 \\
(4.5 \%)\end{array}$ & $\begin{array}{c}6 \\
(2.4 \%)\end{array}$ & $\begin{array}{c}46 \\
(18.6 \%)\end{array}$ \\
\hline
\end{tabular}

Panel B: International M\&As

Target Institution

U.S.

Europe

\begin{tabular}{|c|c|c|c|c|c|c|}
\hline $\begin{array}{l}\text { Acquiring } \\
\text { Institution }\end{array}$ & Banks & Securities & Insurance & Banks & Securities & Insurance \\
\hline $\begin{array}{l}\text { Commercial } \\
\text { Banks }\end{array}$ & $\begin{array}{c}9.5 \\
(13.6 \%)\end{array}$ & $\begin{array}{c}4.4 \\
(6.3 \%)\end{array}$ & $\begin{array}{c}0.2 \\
(0.3 \%)\end{array}$ & $\begin{array}{c}29.5 \\
(16.0 \%)\end{array}$ & $\begin{array}{c}13.0 \\
(7.1 \%)\end{array}$ & $\begin{array}{c}0.7 \\
(0.4 \%)\end{array}$ \\
\hline $\begin{array}{l}\text { Securities } \\
\text { Firms }\end{array}$ & $\begin{array}{c}3.0 \\
(4.3 \%)\end{array}$ & $\begin{array}{c}14.7 \\
(21.0 \%)\end{array}$ & $\begin{array}{c}7.7 \\
(11.0 \%)\end{array}$ & $\begin{array}{c}19.9 \\
(10.8 \%)\end{array}$ & $\begin{array}{c}21.7 \\
(11.8 \%)\end{array}$ & $\begin{array}{c}14.0 \\
(7.6 \%)\end{array}$ \\
\hline $\begin{array}{l}\text { Insurance } \\
\text { Companies }\end{array}$ & $\begin{array}{c}0.6 \\
(0.8 \%)\end{array}$ & $\begin{array}{c}3.9 \\
(5.6 \%)\end{array}$ & $\begin{array}{c}25.9 \\
(37.1 \%)\end{array}$ & $\begin{array}{c}12.2 \\
(6.6 \%)\end{array}$ & $\begin{array}{c}3.4 \\
(1.8 \%)\end{array}$ & $\begin{array}{c}69.7 \\
(37.9 \%)\end{array}$ \\
\hline
\end{tabular}

Sources: DeLong, Smith, and Walter (1998), Berger, Demsetz, and Strahan (1999), and Securities Data Company. The main number shown in each entry is the sum of the equity values (in billions) of the target institutions. The number in parentheses is the percentage of the total (these sum to 100 for each $3 \times 3$ matrix). 